\title{
Impact of Customer Relationship Management Practices on Customer Behavior in Restaurant Industries of Bangladesh
}

\author{
Sayma Sharmen ${ }^{1}$
}

\begin{abstract}
${ }^{1}$ Department of Business Administration, Dhaka International University, 66, Green Road, Dhaka-1205, Bangladesh Correspondence: Department of Business Administration, Dhaka International University, 66, Green Road, Dhaka 1205, Bangladesh, Tel: +8801918346218, Email: sayma.bba@diu-bd.net
\end{abstract}

Received: January 12, 2018

Accepted: January 20, 2018

Online Published: February 4, 2018

\begin{abstract}
The purpose of this paper is to provide proof that consumer relationship management can help to influence customer behavior in restaurant industries (Gloria Jean's, Olympia palace restaurant) and help them to maintain profitable loyal consumers. Data were collected using semi-structured questionnaire and both qualitative and quantitative research methodology was used.There were 60 respondents and the research questionnaire is based on 7 point Likert scale. A key finding was that CRM activities help to develop good relationship with consumers and increase their satisfaction level. Consumers who visited these restaurants often prefer these restaurants over other restaurants. This research was conducted within specific restaurants. The sample size could have been bigger. To further explore the application of CRM in restaurants and the connection of profitability and loyalty with CRM there should be more explicit research.The fact that consumer relationship management is a part of effective and efficient management system and can be essential to ensure retention of consumers. The paper is unique in that we provide evidence of the importance of consumer relationship management in restaurant business where most often no CRM activities is conducted.
\end{abstract}

Keywords: CRM, Customer Behavior, Coupons, Incentives, loyalty, Retention.

\section{Introduction}

In any market, companies want to increase their rate of sales and quality of their services or products regularly to higher and higher points. Bangladesh is no exception. Therefore, In Today's business environment, it is almost impossible to unlink Customer Relationship Management (CRM) and success of the Business. Many researchers have done in order to see how CRM effective and important on the success of the business and which way. In fact, Drucker (1954), suggest, "The true business of every company is to make and keep customers" (Jain and Sharma, 2013, p 47.) which is one of the purposes of CRM. Some call it customer relationship management (CRM); others call it customer experience management, others call it customer-managed relationship (CRM). The aim of present study was to explore a CRM notion and examine CRM practices of one particular business field - restaurants in Dhaka city. The interest for such study arose from two main factors - CRM practices in restaurants of Dhaka city and how CRM could help those particular restaurants especially in Gloria jeans and Olympic palace. In case of restaurants, the switching cost of consumer is little and so consumer loyalty is rare is this sector. But good customer relationship management and service factors can influence consumers to visit same restaurants again and again. For the research purpose we have chosen IDIC model to carry out our investigation. The IDIC model is divided into four elements that include Identify, Differentiate, Integrate and Customize. However, the ten steps proposed by Peppers and Rogers are basically the categorization of the four elements into more explicit tasks that are to be performed by the computers and software technology. This approach has actually played a more important part in simplifying the fundamental CRM practices in to smaller tasks. Therefore, the aim of this paper is to discuss the different customer relationship management practices with the help of technology and technical procedures and explore how this data can help a business. 


\section{Literature Review}

CRM has recently become one of the most controversial issues and a focal-point in the business field (Balaram and Adhikari, 2010; Becker et al., 2009; Dimitriadis and Steven, 2008; Ozgener and Iraz, 2006). It is worth mentioning that CRM is mainly based on the belief that establishing a sustainable relationship with customers is the cornerstone for obtaining loyal customers who are much more profitable than non -loyal ones (Dowling, 2002). In this regard, the successful implementation of CRM strategy will be of great benefit to the organizations, adopting it, as such organizations can reap the benefit of increasing sales through better market segmentation, customizing products and services, obtaining higher quality products, gaining access to information and employee satisfaction, and above all, ensuring long-lasting customer-retention and loyalty (Alomtairi, 2009; Ozgener and Iraz, 2006; Stockdale, 2007; Verma and Chandhuri, 2009).

Moreover, we have to bear in mind that recent studies on the CRM selectively focus on some service sectors, such as banking (e.g. Akroush et al., 2011; Becker , Greve, and Albers 2009; Eid, 2007; Hussain et al., 2009; Krasnikov et al., 2009; Sin, Tse and Yim 2005), telecommunication (e.g. Almotairi, 2009; Beldiet al., 2010), healthcare (e.g. Bunthuwun et al., 2011; Hung et al., 2010), and contact center (Abdullatif et al., 2010). Consequently, there is still a marked lack of research on CRM in the hospitality industry (Luck and Stephenson, 2009; Wu and Lu, 2012). So it is not a surprise to find Vogt's highlighting this concept. He says, although there is ever-increasing use of CRM in the tourism sector, there are still limited researches investigating its variety of applications in such significant industry (Vogt, 2011). Furthermore, several researches refer to the importance of making studies on CRM dimensions in the restaurant sector (Akroush et al., 2011; Sadek et al., 2011; Sin et al., 2005). As a result of that, it is reasonable to lead the conclusion that it is not only very little attention has been given to the CRM dimensions in the hotel industry, but there is also plenty of opportunity for extending the literature about CRM dimensions and restaurant performance, both theoretically and empirically.

Today for most of the organizations, one of the most important challenge and goal is customer retention. A research in restaurant industry, practicing CRM has revealed that, most of the restaurant in sample were practicing CRM, but those who were graded higher had more complicated system in place. Moreover, very few restaurants had a regular system of investigating customer complaints and tracking them. Most of the restaurants were capturing considerable customer data, but very few were analyzing data to minimize guest failures, and thus repeating the dame mistake. None was extensively mining data to identify most profitable customers. However, most of the restaurant practicing effective CRM are successful in retaining customers means that CRM practices also have a direct relation with the customer retention, (Lo et al, 2012)."Sharing of information from one person to another person or groups has risen in past decades, through human communication such as face-to-face contact, telephone, correspondence (letters, email, text messaging) or social media", (Gombesk et al, 2011).Increasingly customers heavily rely on word of mouth, for purchase of virtually everything. Power of word of mouth becomes more critical with the fact that negative word of mouth tend to spread more rapidly than positive WOM, (Aslam et al, 2011). In this age of micro media, where there is wide use of internet and mobiles, word of mouth has gained the popularity of determining success factor marketing. The changing life styles have impacted consumer behavior and purchasing patterns. Power of WOM is increasing rapidly, as it was reported to have $61.3 \%$ influences on purchase decision which reached to $76 \%$ in 2007. It means marketers cannot avoid the power of WOM now. In this competitive age, CRM if practiced effectively, can have the power to generate positive word of mouth, while, if not managed properly, it can also have adverse effects and can result in negative word of mouth, (Kokokusha co., Ltd, 2007). It also has great impact on customer decision making. So, organizations must have to keep a track of word of mouth spread by its existing customers, as they will ensure new loyal customers. Satisfied and delighted customers are a source of positive word of mouth, (Heriyati \& Siek, 2011).

One prominent aspect of CRM is to deal each customer differently, based on the idea that each customer has different needs. Moreover, CRM involves identifying the most profitable customers and maintaining good relationship with them. But if overly used and misused, it can pose a threat for the firm. Different treatment with different customers may harm customers' trust and they may perceive it as discrimination. So, in implementing CRM, firms must have to address this issue in order to avoid dissatisfaction, (Nguyen \& Mutum, 2012). Customers that possess relational satisfaction are more likely to be involved in the activities of positive word of mouth. Customers that identify themselves with the organization are also retained customers, (Akm, et al, 2011). Service quality has a direct and positive impact on customer satisfaction. Satisfied customers are less, price sensitive and are more likely to tell other people about their favorite experience. Customer satisfaction also affects customer loyalty. Further service quality also has a direct impact on customer loyalty. So the service quality is related to repeat purchases, and positive word of mouth, (Chotivanich, 2012). It is generally believed that effectiveness of CRM should be measured in terms of customer's behaviors. Some researchers have checked the effectiveness of CRM in terms of firm profitably, but profitability in a particular period of time may be the result of combination of some 
factors. Although researches have been conducted to check impact of CRM practices on customer satisfaction and loyalty, customer satisfaction and customer loyalty are intangible reactions or perceptions of customers. But for companies applying CRM, tangible actions of customers are more important. So CRM applying firms must give importance to customer retention and word of mouth, and repurchase that are the tangible outcomes of CRM, (Wang et al, 2004).

3. Objectives of the Research

The main objective of the research is measuring the impact of customer relationship management practices on customer behavior in restaurant industries of Bangladesh.

Other objectives are-

- To identify CRM practices of restaurant of Gloria Jean's and Olympia palace restaurant

- Identify the role of CRM in restaurant.

- To identify the importance of CRM that contributes to customer satisfaction and retention.

- To recommend some action plan to increase profitability and loyalty of restaurant. 4. Variables in the Research :( For Customer Survey)

\begin{tabular}{|c|c|}
\hline Dependent Variable & $\begin{array}{l}\text { CRM Impact On Customer } \\
\text { Behavior }\end{array}$ \\
\hline \multirow[t]{7}{*}{ Independent Variables } & Customer collaboration \\
\hline & Customer touch point \\
\hline & Customer feedback \\
\hline & Customer relationship \\
\hline & Self-service capability \\
\hline & Service availability \\
\hline & Service Quality \\
\hline
\end{tabular}

\section{Research Methodology}

There are two distinct research methods - quantitative and qualitative, in collecting data for the purpose of obtaining information from them, to solve or answer a particular research problem or question (Ghauri \& Gronhaug 2005, p109). And for this study we have followed both qualitative as well as quantitative research methodology.

Qualitative research that we conducted on the company management and employees are in-depth interview, and survey study were used as research techniques that conducted on Gloria jeans and Olympia Palace restaurant's customer. The available literature used through reviewing different articles, books, periodicals, journals, etc., and relevant websites. Primary data were obtained through a sample survey conducted on 60restaurant's customer and in depth interviews were conducted by a semi-structured questionnaire to restaurants management. Sources of significant secondary information included the sales data, newspapers, Facebook pages, brochures of restaurant and customers fan pages. The probability simple random sampling technique will be used in which the sample elements will be selected randomly. We have a sample of 60 respondents in Dhaka city. Data has been collected both from male and female respondents. Here the research focuses on a geographical area; the research reach individuals whose age range from 25 to 50+ years. As more responses will result higher credibility of the findings we tried to gather enough response.

The survey was carried out in the form of questionnaire. Since there was only one chance to collect the data, the researcher had to identify precisely of what data is needed, and to design the questionnaire in order to meet the research objectives (Saunders et al. 2009). In order to ensure respondent decodes the questions in the way the researcher intended, the clarity of the questionnaire structure was a dominant factor. Moreover the appropriate length and logical order of the questions in the questionnaire is also important. The questionnaires were provided directly to the respondents and we, the surveyors, recorded the collected data. These were collected via convenience sampling method. We have chosen respondents within the target population who were representative of different segments. No supervisory and validation method was used. The data required for conducting this study was collected using self-administered questionnaires, specially designed to achieve the study goals. While we prepared a question, we tried to avoid leading and loaded questions, and we have also made our questionnaire easy and to the point, so that it would help us to solve our research problem. For this purpose we have used 7 point Likert scale and observing questions that allow the respondents to give multiple answers to a single question. It is a cross sectional 
analytical study. It is providing an overview about the perceptions and behaviors of respondents about CRM practices. Associations between different variables have been checked through hypothesis, which has made it an analytical study.

Target Population:

Elements: Customer of Gloria jeans and Olympia Palace restaurant

Sampling Unit: Areas (Dhanmondi and Gulshan 1)

\section{Extent: Dhaka City}

Time: 2015.

In a research process, data analysis is one of the significant parts for a researcher. In this research, data has been collected through actual format for both quantitative and qualitative approaches. The researcher will use SPSS 17 software for the processing of collected data through questionnaires and other sources. Moreover, SPSS 17 analysis helps to get charts and diagrams those are easily understandable. Regression and factor analysis are used here for understanding customer behavioral impact on CRM.Even, for analyzing interview data, used template analysis, which will ensure good analysis for quantitative data.

The regression model that will be used is as follows:

$\mathbf{Y}=\mathbf{B} 0+\mathbf{b}_{1} \mathbf{X}_{1}+\mathbf{b}_{2} \mathbf{X}_{2}+\mathbf{b}_{3} \mathbf{X}_{3}+\mathbf{b}_{4} \mathbf{X}_{4}+\mathbf{b}_{5} \mathbf{X}_{5}+\mathbf{b}_{6} \mathbf{X}_{6}+\mathbf{b}_{7} \mathbf{X}_{7}+e$

Where: $\mathrm{Y}=\mathrm{CRM}$ impact on customer behavior.

$\mathrm{B}_{0}=$ Constant of variables.

$\mathrm{X}_{1}=$ Customer collaboration, $\mathrm{X}_{2}=$ Customer touch point, $\mathrm{X}_{3}=$ Customer feedback, $\mathrm{X} 4=$ Customer relationship, $\mathrm{X} 5=$ Self-service capability, $\mathrm{X}_{6}=$ Service availability $\mathrm{X}_{7}=$ Service quality.

\section{Data Analysis and Interpretation}

\subsection{Important Approaches Used By Gloria Jean's And Olympia Palace}

The mantra for a restaurant's revenue and profit growth is centered on delivering consistent and satisfying customer experience. Here, Gloria Jean's and Olympia Palace restaurant has initiated some ideologies and functions that help them to remain profitable.

\subsection{Common Themes and Connections of Gloria Jean's Coffees and Olympia Palace Restaurant}

- Both these restaurants reach their customers mainly through social networking sites like- face book; twitter etc.

- Sometimes these restaurants use emails, sms, promotional offers and telephone calls for gathering information about their current customers to gain loyalty.

- Both restaurants have online order taking mechanism and home delivery facility

- Both restaurants have several payment methods which are really convenient to the customers. For example both restaurants accept American express, visa, master card.

\subsection{Activities that Relate Customers Experience to CRM of Gloria Jean's and Olympia Palace Restaurant}

- Gloria Jean's Bangladesh use customer suggestion form to gain knowledge about the customer experience at the restaurant.

- Olympia Palace gathers data and thus identifies customer preferences by successfully measuring their customer satisfaction forms that are being given after every meal.

- During less occupancy period, Gloria Jean's target various promotional and sale increasing campaigns to attract more and new customers to achieve greater loyalty.

- Olympia palace restaurant always filter the customers with the initiative that make the customers more and more active in the promotional campaign of the restaurant.

- Olympia Palace restaurant always encourage customers to revisit by offering loyalty cards and other facilities like free foods and cash back offers.

- Gloria Jean's always have the intention to recognize frequent customers and offering them add on benefits for their attachment to the restaurant as a part of the loyalty program of the restaurant. 


\subsection{Qualitative Overview of Gloria Jean's Coffees Dhaka Based on IDIC MODEL}

The description of Gloria Jeans can be easily depicted with the help of I-D-I-C model. Here the model is given below-

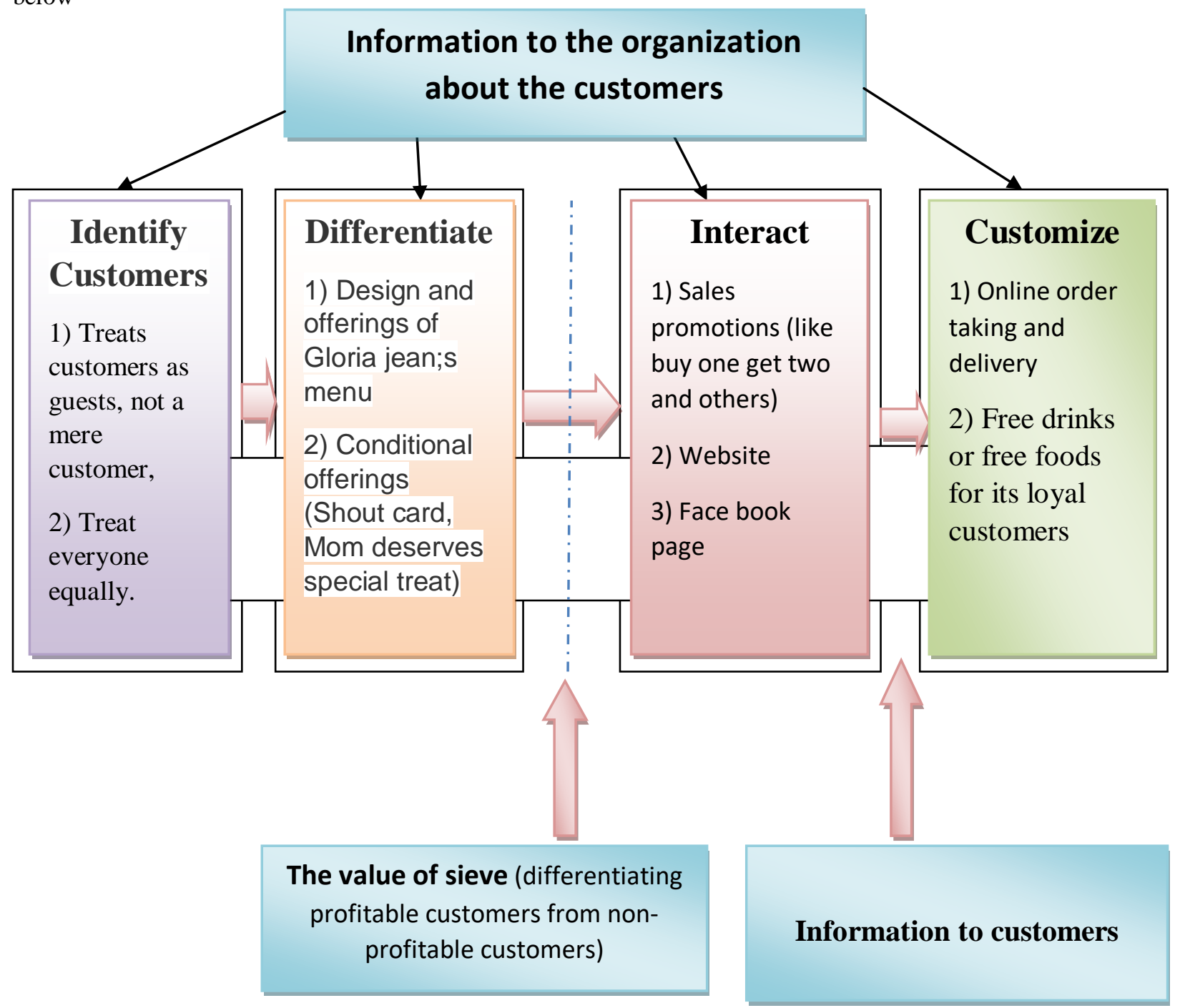

Figure-1: Information to the organization about the customers (IDIC MODEL)

From the above model, the various customer relationship management aspects of Gloria Jean's Coffees Bangladesh is being described below-

In IDIC model, the first thing about the customer relationship activities is to identify the target customers as individual persons and then to persuade them that the restaurant is established to serve for them. For exampleGloria Jean's always treats its customers as guests, not a mere customer, and treat everyone equally whether they are new or old. The second thing in IDIC model is to differentiate the customers by their value to the restaurant. For example- Gloria Jean's sometimes connected through Facebook and makes a good relationship with its customers in the online zone.

IDIC model has the activity to differentiate the customers by their needs from their organization. For exampleGloria Jean's always offers different assortment of foods and special offers.

IDIC model consists of the theory of interaction with all the customers according to the value and need because it brings much better connection between customers and company. For example- Gloria Jean's sometimes offer various sales promotions like buy one get two and others.

IDIC model has the ability to persuade the company for customizing the products and services according to their customer's needs and wants. For example- Gloria Jean's sometimes initiates free drinks or free foods for its loyal customers who are the regular members of the restaurant. 
It is now clear that, Gloria Jean's Coffee Bangladesh has a great amount of customer relationship activities that are very helpful in retaining its present customers and attracting its new customers.

6.5 Qualitative Overview Olympia Palace Restaurant Dhaka Based On I-D-I-C Model

Now, the customer relationship assessment of Olympia Palace by using the IDIC model is given below- Olympia palace always identifies its customers by using the word-of-mouth aspects and through online advertisements like ads in Facebook or google or other social networking sites. The implication of IDIC model can easily be seen here because the first thing in IDIC model is to identify customers as individuals and let them know that the organization knows them very well and this thing is very much seen in the eye catching ads of Olympia Palace.

IDIC model's second activity that means the differentiation of customers by their value to the organization is also a thing that must be categorized through a dedicated amount of value creation activities. For example- Olympia Palace always provides a loyalty card to its new customers to make a relationship with them.

The third activity that is seen in the IDIC model is the differentiation of customers by their needs from the organization. For example- Olympia Palace restaurant always differentiates its customers through relevant attitudes and make them feel that all their required needs will be fulfilled by the restaurant always.

IDIC model always interact with the customers to offer the value to them. For example- Olympia Palace restaurant always provides different free food items when the customers show them loyalty cards. One of the most important activities of IDIC model is to customize products and services according to customers' needs and Olympia Palace restaurant always try to do this function by offering different foods at different occasions to their customers. The description of Olympia palace Dhaka can be easily depicted with the help of I-D-I-C model. Here the model is given below-

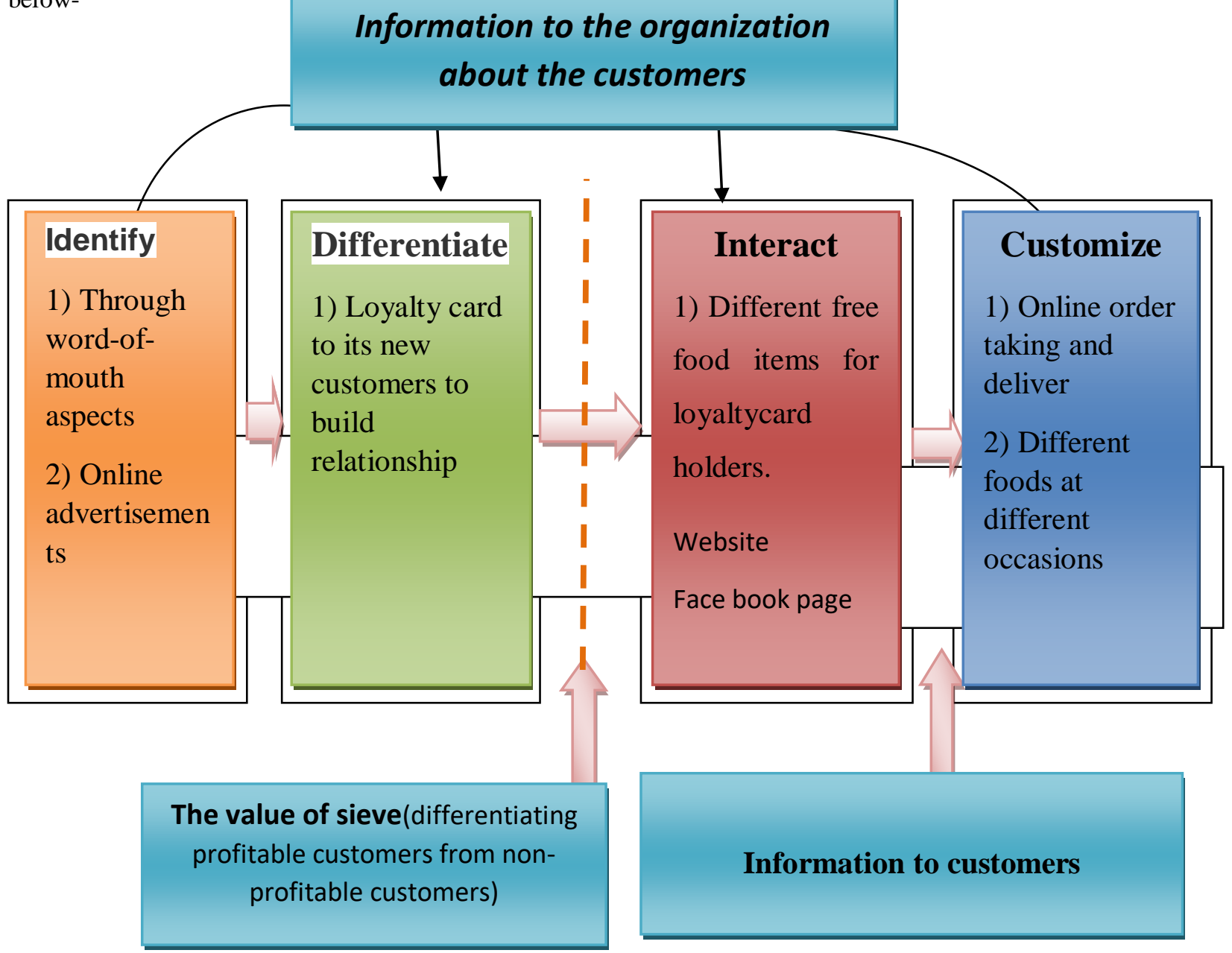

Figure-2: Information to the organization about the customers (I-D-I-C Model) 


\subsection{Statistical Output}

\begin{tabular}{|c|c|c|}
\hline \multicolumn{3}{|c|}{ Frequencies } \\
\hline \multicolumn{3}{|c|}{ Gender } \\
\hline \multirow[t]{2}{*}{$\mathrm{N}$} & Valid & 60 \\
\hline & Missing & 0 \\
\hline
\end{tabular}

\begin{tabular}{llllll}
\hline Gender & & & & \\
\hline \multirow{3}{*}{ Valid } & Frequency & Percent & Valid Percent & $\begin{array}{l}\text { Cumulative } \\
\text { Percent }\end{array}$ \\
\cline { 2 - 6 } & Male & 25 & 41.7 & 41.7 & 41.7 \\
\cline { 2 - 6 } & Total & 60 & 58.3 & 58.3 & 100.0 \\
\hline
\end{tabular}

Descriptive statistics showed that majority of these fast food restaurant customers is male, that is 58.3. Females are only 41.7 of total customers respond in this study. There is no missing value that means all the customer respond properly.

\begin{tabular}{|c|c|c|c|}
\hline \multicolumn{4}{|l|}{ Correlations } \\
\hline & & Customer feedback & $\begin{array}{l}\text { CRM impact on } \\
\text { customer behavior }\end{array}$ \\
\hline \multirow[t]{3}{*}{ Customer feedback } & Pearson Correlation & 1 & $.483^{* *}$ \\
\hline & Sig. (2-tailed) & & .000 \\
\hline & $\mathrm{N}$ & 60 & 60 \\
\hline \multirow[t]{3}{*}{ CRM impact on customer behavior } & Pearson Correlation & $.483^{* * \%}$ & 1 \\
\hline & Sig. (2-tailed) & .000 & \\
\hline & $\mathrm{N}$ & 60 & 60 \\
\hline
\end{tabular}

In the chart when we correlate one independent and one dependent variable we found that there is a positive relationship between them and that is 1 it is significant at 0.01 level in 2-tailed test.

\begin{tabular}{lllll} 
Regression & & & & \\
\hline Model & R & R Square & Adjusted R Square & $\begin{array}{l}\text { Std. } \\
\text { Estimate }\end{array}$ \\
\hline 1 & $.749^{\mathrm{a}}$ & .561 & .699 & 1.182 \\
\hline 2 & $.847^{\mathrm{b}}$ & .717 & .708 & .957 \\
\hline 3 & $.871^{\mathrm{c}}$ & .759 & .746 & .892 \\
\hline 4 & $.882^{\mathrm{d}}$ & .777 & .761 & .866 \\
\hline 5 & $.891^{\mathrm{e}}$ & .794 & .775 & .840 \\
\hline
\end{tabular}

Here, the regression analysis is constructed by taking independent variable as number of restaurant CRM factor and dependent variable as CRM impact on behavior. In the following table, the difference between $\mathrm{R}$ square and adjusted R Square is very low .50(.749-.699). Therefore, CRM factor on Customer Behavior is very significant and positive.

\begin{tabular}{lllllll}
\hline ANOVA $^{\mathbf{f}}$ & & & & \\
\hline Model & & Sum of Squares & df & Mean Square & F & Sig. \\
\hline 1 & Regression & 103.761 & 1.5 & 103.761 & 7.216 & $.000^{\mathrm{a}}$ \\
\cline { 2 - 7 } & Residual & 81.089 & 58 & 1.398 & \\
\cline { 2 - 7 } & Total & 184.850 & 59 & 66.308 & 7.359 & $.000^{\mathrm{b}}$ \\
\hline 2 & Regression & 132.616 & 2 & .916 & \\
\cline { 2 - 6 } & Residual & 52.234 & 57 & & & \\
\hline
\end{tabular}




\begin{tabular}{|c|c|c|c|c|c|c|}
\hline & Total & 184.850 & 59 & & & \\
\hline \multirow[t]{3}{*}{3} & Regression & 140.299 & 3 & 46.766 & 5.784 & $.000^{\mathrm{c}}$ \\
\hline & Residual & 44.551 & 56 & .796 & & \\
\hline & Total & 184.850 & 59 & & & \\
\hline \multirow[t]{3}{*}{4} & Regression & 143.638 & 4 & 35.910 & 4.924 & $.000^{\mathrm{d}}$ \\
\hline & Residual & 41.212 & 55 & .749 & & \\
\hline & Total & 184.850 & 59 & & & \\
\hline \multirow[t]{3}{*}{5} & Regression & 146.770 & 5 & 29.354 & 4.625 & $.000^{\mathrm{e}}$ \\
\hline & Residual & 38.080 & 54 & .705 & & \\
\hline & Total & 184.850 & 59 & & & \\
\hline
\end{tabular}

From statistical appendix, the critical value of $\mathrm{F}$ for 7.216 degree of freedom is 1.5 . The calculated value of $\mathrm{F}$ is larger than the critical value. Here, the significance of ANOVA is $.000<0.5$ (less than 0.5 level). So, the estimated result is satisfactory and the findings seem plausible.

Therefore, the findings state that the customers are well satisfied with the company's CRM practices. Reliability

\begin{tabular}{llll}
\hline \multirow{3}{*}{ Cases } & & $\mathbf{N}$ & $\mathbf{\%}$ \\
\cline { 2 - 4 } & Valid & 60 & 100.0 \\
\cline { 2 - 4 } & Excluded & 0 & .0 \\
\cline { 2 - 4 } & Total & 60 & 100.0 \\
\hline
\end{tabular}

\begin{tabular}{ll}
\hline Reliability Statistics & \\
\hline Cronbach's Alpha & Number of Items \\
\hline .755 & 3 \\
\hline
\end{tabular}

As the scale used for data collection is a Likert scale, so, in order to check its reliability, high quality reliability test is required. Normally, an index of reliability, alpha is used, for this purpose. It is a measure of internal consistency. Reliability estimates and ranges from 0 to 1 . Higher the score of the index higher the reliability of the instrument designed. Alpha below 0.59 is not reliable. If alpha have a value of 0.6 it is not very much reliable, however a value of 0.7 or above is considered to be sufficiently reliable. The present research has used five constructs and the questionnaire is having a 7 point Likert scale, so alpha has been used to check the internal consistency reliability. The measurement scale for this study is showing a very good value of alpha, that is 0.755 . This means that the developed scaled is $75.5 \%$ reliable in measuring the constructs.

Factor Analysis

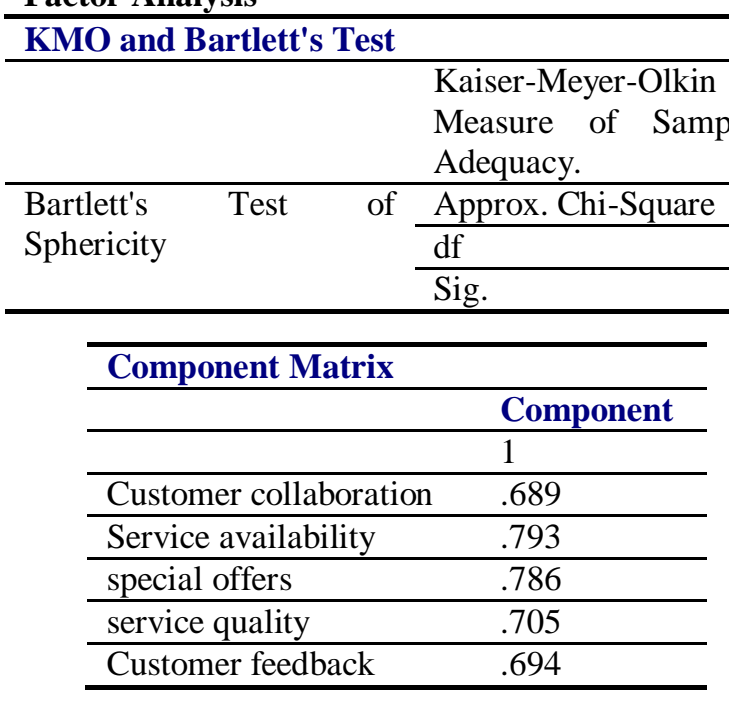

\begin{tabular}{lll} 
Communalities & & \\
\hline & Initial & Extraction \\
\hline Customer collaboration & 1.000 & .474 \\
\hline Service availability & 1.000 & .628 \\
\hline special offers & 1.000 & .618 \\
\hline service quality & 1.000 & .497 \\
\hline Customer feedback & 1.000 & .482 \\
\hline $\begin{array}{l}\text { Extraction Method: } \\
\text { Analysis. }\end{array}$ & Principal & Component \\
\hline
\end{tabular}


Initially there were 7 questions in the scale for Customer Relationship Management. Through CFA, 3 questions were identified those were confirmed in factor analysis but as per there very low values, were not much important in measuring the construct of CRM. So, 5 items were finalized to measure the construct of CRM. Out of these 5 items, 3 items, namely, service availability, special offer, Service quality with the values of $0.739,0.786$ and 0.705 respectively are most important items. So among the 5 variable these three has high impact on companies CRM.SO customer has high impact on CRM practice.

Results of the study are based on cross sectional data. This type of study is best where hypothesis generation and attestation is involved. It helps in finding out association between different variables; however it is not suitable when objective is to find the cause of a problem. So to get better understanding of the mechanism, and for broad generalization and validation of the study, a longitudinal research must be conducted. Before conducting the actual research, the instrument was pilot tested on a sample of 60 customers. The reliability results show a cronbach alpha of .755, which shows a strong value. For standard questionnaire alpha's value above 0.7 is considered to be good. However for newly developed questionnaire a value above 0.5 is also acceptable. It was found that CRM has a direct relationship with customer behavior. Customer positive behavior is found to have associations with customer satisfaction and customer loyalty. The continuous interaction leads them to develop positive perceptions about the organization and they feel satisfied while going to restaurant. Final model revealed a direct relationship between customer behaviors and companies CRM. So the research hypothesis is accepted as CRM has positive impact on customer's behavior.

7. Recommendation

Unlike many restaurants operating in Bangladesh Gloria Jeans and Olympia Palace use CRM to improve and maintain their position. But they have some limitations that they have to overcome. And for that we have some recommendation for both restaurants that may be beneficial for these restaurants.

7.1 Recommendation for Improving CRM to Gloria Jean's Coffees

Some recommendations for Gloria Jean's include-

In the whole Dhaka city there is only one outlet of Gloria jean's coffees which is located in gulshan-1 and Dhanmondi. They should increase their outlets.

It lacks the BANGALIANA flavor. If they include some local items, it would help them to capture more segments in the market.

Sometimes the items it offers can be way too much overpriced. This is not convenient for some customers.

7.2 Recommendation for Improving CRM to Olympia Palace

Some recommendations for Olympia Palace are given below-

As Olympia palace is relatively new restaurants, it requires frequent advertising. And the best way can be social media advertising.

Olympia palace can offer discount on graduation dinner party to make its prospective customers aware of the outlet. The employee should be thoroughly trained so that they can handle customers with more passion and care.

8. Limitation of the Research

Here the theories were approved by findings from survey and the research is able to provide a certain degree of new insights in relating to the current situation but yet some limitations may still exist.

- The above findings cannot represent all individuals who visits these restaurants,

- The behavior of individuals may differ in similar situation and may not respond to same CRM activities.

- The research result may lack objectivity and Time Constraints.

9. Conclusion

Findings of this research provide insights into the mechanism that impact the customer behavior. Research has investigated the impact of CRM practices on different customer attitudes and behaviors. The empirical results of the study proved that CRM does have direct impact on customer behavior. These results are consistent with the results of previous researches, (Zali \& Heydarian, 2012). Positive customer behavior leads positive customer experience and customer satisfaction. Customer satisfaction and experience affects the customer loyalty and customer retention. As majority customers of these restaurants are the urban citizens, dinning out frequently has become a part of their life style. It is not a luxurious thing anymore. So the CRM practices neither make these customers loyal nor get them to speak for these restaurants. However these practices provide them a good and memorable experience and get them satisfied. This satisfaction and good experience, in turn, positively impact the customer loyalty and retention.

References

Abbasi, A.S., Khalid, W., Azam, M., \&Riaz, A. (2010). Determinents of customer satisfaction in hotel industry of Pakistan. Eurepian Journal of Scientific Research, 48(1), 97-105.

Almotairi, M. (2009). A Framework for CRM Success. 
Becker, U. G. (2009). The Impact of Technological and organizational Implementation of CRM on Customer Acquisition, Maintenance and Retention. International Journal of Research in Marketing, 207-215.

Balaram, A. A. (2010). Managing Customer Relationship in Service Organizations. Administration and Management Review.

Baig, A. K, \&Saeed,M. (2012). Review of trends in fast food consumption. European Journal of Economics, Finance and Administrative Sciences, 48.

Chauey, D., Joshit,SZafar, S.M.T. (2010). An assessment of customer relationship management practices opted by banks for retaining customers in Uttrakhand State. International Transactions in Humanities and Social Sciences, 2(2), 205_217.

Customer-relationship-management performance: A customer-based perspective from China. Managing Service Quality, 14(2), $169-182$.

Ezaz, R., Ahmed, M. A., \& Ahmad, Z. (2013). Impact of CRM practices on Consumers' Behavior. International Journal of Business and Management Inventions.

Ghauri, P. \&. (2002). Research Methods in Business Studies: A Practical Guide. Financial Times.

Hashem, T.N., (2011). The impact of customer relationship marketing on customers' image for Jordanian five star hotels. Journal of Academic Research in Economics, 3 (3).

Khandekar, A. N, \& Deshmukh, U.M, (2012). CRM (Customer relationship management). Golden Research Thoughts, 2, (1).

Kamakura, W., Mela, C. F., Ansari, A., Bodapati, A., \& Fader, P., (2005). IDIC models and customer relationship management. Marketing Letters, 16(3), 279-291.

Ken Burnett (2015). KCRM (key customer relationship management). Edition 2015-2016.

Lo, A. S., Stalcup, L. D., \& Lee, A., (2010). Customer relationship management for hotels in Hong Kong. International Journal of Contemporary Hospitality Management, 22( 2), 139 - 159

Mithas, S., Krishnan, M.S., Fornell, C., (2009). Why do customer relationship management applications affect customer satisfaction? Journal of Marketing, 69(4), 201-209.

Malhotra, N. \&. (2012). Marketing Research: An Applied Orientation (6th Ed.). India: Dorling Kindersley.

Mohammed, A. A., \& Rashid, B. B. (2012). International Review of Management and Marketing Customer Relationship Management (CRM) in Hotel Industry: A. International Review of Management and Marketing, 220-230.

Osarenkhoe, A., Bennani, A., (2007). An exploratory study of implementation of customer relationship management strategy. Business Process Management Journal, 13(1), 139-164.

Qian, S., Peiji, S. \&Quanfu, Y, (2011). An integrated analysis framework for customer value, customer satisfaction, switching barriers, repurchase intention and attitudinal loyalty: Evidences from China mobile data service. Management Science and Engineering, 5(3), 135-142.

Rameeza Ejaz, Mirza Ashfaq Ahmed, Zahoor Ahmad (2013). Impact of CRM Practices on Customers' Behaviors, Volume 2 Issue 7, PP.79-88

Rozin, P., Fischiler, C., Imada, S. \& Wrzesniewski, A, (1999). Attitudes to food and role of food in life in the U.S.A., Japan, Flemish Belgium and France: Possible Implications for the diet-health debate. Appetite, 33, $163-180$

Saunders, M. L. (2009). Research Methods for Business Students (Fifth Ed.). England: Pearson Education Limited.

Yee, J., Lam, S.Y, \& Lee, T.C, (2012).Service quality, customer satisfaction and behavioral intentions: Review of literature and conceptual model development. International Journal of Academic Research, 4(3).

Appendixes

Appendix A : Questionnaire

A survey questionnaire on measuring the "Impact of Customer Relationship Management practices on customer behavior in restaurant industries of Bangladesh" (Customer Survey)

This is a descriptive survey to be conducted on different customers in restaurant Industry in Bangladesh. The survey will help us understand the impact CRM practices on customer behavior.

Q1. What is your gender?

O Male (1)

Female (2) 
Q2. Do you think the company involve customer in creating new offers?

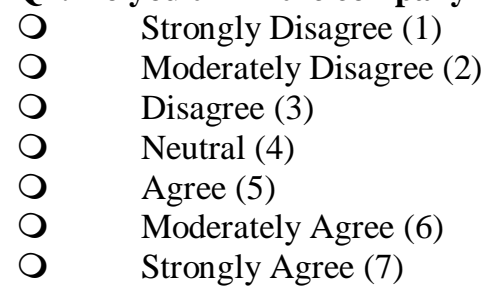

Q3. Do you think the company treats customer personally?

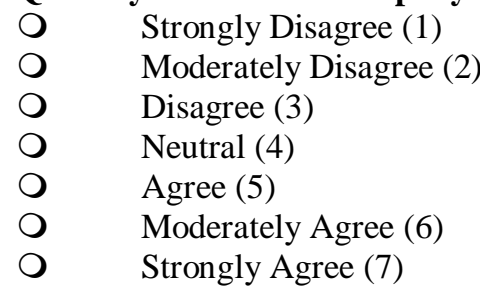

Q4. How do you rate the Following Statement?

"Company considers customers suggestions to improve the service level."

O Strongly Disagree (1)

O Moderately Disagree (2)

O Disagree (3)

O Neither Agree nor Disagree (4)

O Agree (5)

O Moderately Agree (6)

O Strongly Agree (7)

Q5. How do you rate the Following Statement?

"The company does not build relationship with key customers."

O Strongly Disagree (1)

Moderately Disagree (2)

O Disagree (3)

Neither Agree nor Disagree (4)

O Agree (5)

O Moderately Agree (6)

O Strongly Agree (7)

Q6. How do you rate the Following Statement?

"The company has a self-service capability to provide customers more control."

O Strongly Disagree (1)

O Moderately Disagree (2)

O Disagree (3)

O Neither Agree nor Disagree (4)

O Agree (5)

O Moderately Agree (6)

Strongly Agree (7)

Q7. Do you think the service is available whenever you needed?

O Strongly Disagree (1)

O Moderately Disagree (2)

O Disagree (3)

O Neither Agree nor Disagree (4)

O Agree (5)

O Moderately Agree (6)

Strongly Agree (7) 
Q8. Do you think the special offers provided by this restaurant will lead customers to revisit?

O Strongly Disagree (1)

O Moderately Disagree (2)

O Disagree (3)

O Neither Agree nor Disagree (4)

O Agree (5)

O Moderately Agree (6)

O Strongly Agree (7)

Q9. Do you think the restaurant should give more importance to service quality?

O Strongly Disagree (1)

O Moderately Disagree (2)

O Disagree (3)

O Neither Agree nor Disagree (4)

O Agree (5)

O Moderately Agree (6)

Strongly Agree (7)

Q10. Do you think this restaurant need to improve their CRM activities?

Q Strongly Disagree (1)

O Moderately Disagree (2)

O Disagree (3)

O Neither Agree nor Disagree (4)

O Agree (5)

O Moderately Agree (6)

O Strongly Agree (7)

Q11. Finally do you think Customer Relationship Management (CRM) practices of the company have an impact on your behavior?

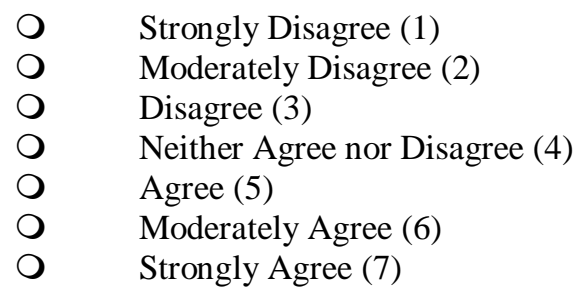

\section{Appendix B : Questionnaire in Depth Interview Questionnaire}

- What is the name of your organization?

- What is your position in organization hierarchy-Top management or Middle-level management?

- Do your organization provides customized services and products to your key customers?

- Do all people of your organization treat key customers with great care?

- Do your employee training programs are designed to develop the skills required for acquiring and deepening customer relationships?

- Do your organization commits time and resources in managing customer relationships?

- Do employee performance is measured and rewarded based on meeting customer needs and on successfully serving the customer?

- Do your organization has the right technical personnel to provide technical support for the utilization of computer technology in building customer relationships?

- Do your company have individual customer information is available at every point of contact?

- Do your organization maintains a comprehensive database of our customers? 
Appendix B: SPSS Output

\section{Frequencies}

\begin{tabular}{llr}
\hline \multicolumn{3}{l}{ Statistics } \\
\hline Gender & \\
\hline $\mathrm{N}$ & Valid & 60 \\
\cline { 2 - 3 } & Missing & 0 \\
\hline
\end{tabular}

\begin{tabular}{llrrrr}
\hline \multicolumn{7}{c}{ Frequency } & Percent & Valid Percent & \multicolumn{1}{c}{$\begin{array}{c}\text { Cumulative } \\
\text { Percent }\end{array}$} \\
\hline \multirow{2}{*}{ Valid } & Female & 25 & 41.7 & 41.7 & 41.7 \\
\cline { 2 - 6 } & Male & 35 & 58.3 & 58.3 & 100.0 \\
\cline { 2 - 6 } & Total & 60 & 100.0 & 100.0 & \\
\hline
\end{tabular}

\section{Correlations}

\section{Gender}

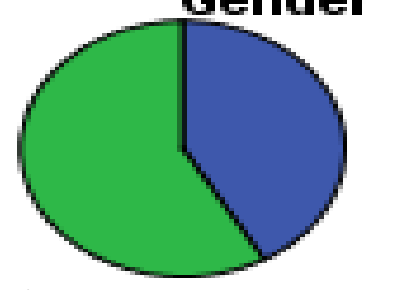

Female

Male

\begin{tabular}{|c|c|c|c|}
\hline \multicolumn{4}{|c|}{ Correlations } \\
\hline & & $\begin{array}{l}\text { Customer } \\
\text { feedback }\end{array}$ & $\begin{array}{c}\text { CRM impact } \\
\text { on customer } \\
\text { behavior }\end{array}$ \\
\hline \multirow[t]{3}{*}{ Customer feedback } & Pearson Correlation & 1 & $.483^{* *}$ \\
\hline & Sig. (2-tailed) & & .000 \\
\hline & $\mathrm{N}$ & 60 & 60 \\
\hline \multirow{3}{*}{$\begin{array}{l}\text { CRM impact on customer } \\
\text { behavior }\end{array}$} & Pearson Correlation & $.483^{* * *}$ & 1 \\
\hline & Sig. (2-tailed) & .000 & \\
\hline & $\mathrm{N}$ & 60 & 60 \\
\hline
\end{tabular}

\section{Regression}

\begin{tabular}{|c|c|c|c|c|}
\hline \multicolumn{5}{|c|}{ Model Summary } \\
\hline $\begin{array}{l}\text { Mode } \\
1\end{array}$ & $\mathrm{R}$ & R Square & $\begin{array}{l}\text { Adjusted R } \\
\text { Square }\end{array}$ & $\begin{array}{l}\text { Std. Error of } \\
\text { the Estimate }\end{array}$ \\
\hline 1 & $.749^{\mathrm{a}}$ & .561 & .554 & 1.182 \\
\hline 2 & $.847^{\mathrm{b}}$ & .717 & .708 & .957 \\
\hline 3 & $.871^{\mathrm{c}}$ & .759 & .746 & .892 \\
\hline 4 & $.882^{\mathrm{d}}$ & .777 & .761 & .866 \\
\hline 5 & $.891^{\mathrm{e}}$ & .794 & .775 & .840 \\
\hline \multicolumn{5}{|c|}{ a. Predictors: (Constant), Self-service capability } \\
\hline \multicolumn{5}{|c|}{$\begin{array}{l}\text { b. Predictors: (Constant), Self-service capability, Customer touch } \\
\text { point }\end{array}$} \\
\hline \multicolumn{5}{|c|}{$\begin{array}{l}\text { c. Predictors: (Constant), Self-service capability, Customer touch } \\
\text { point, service quality }\end{array}$} \\
\hline \multicolumn{5}{|c|}{$\begin{array}{l}\text { d. Predictors: (Constant), Self-service capability, Customer touch } \\
\text { point, service quality, special offers }\end{array}$} \\
\hline
\end{tabular}


e. Predictors: (Constant), Self-service capability, Customer touch point, service quality, special offers, Customer collaboration

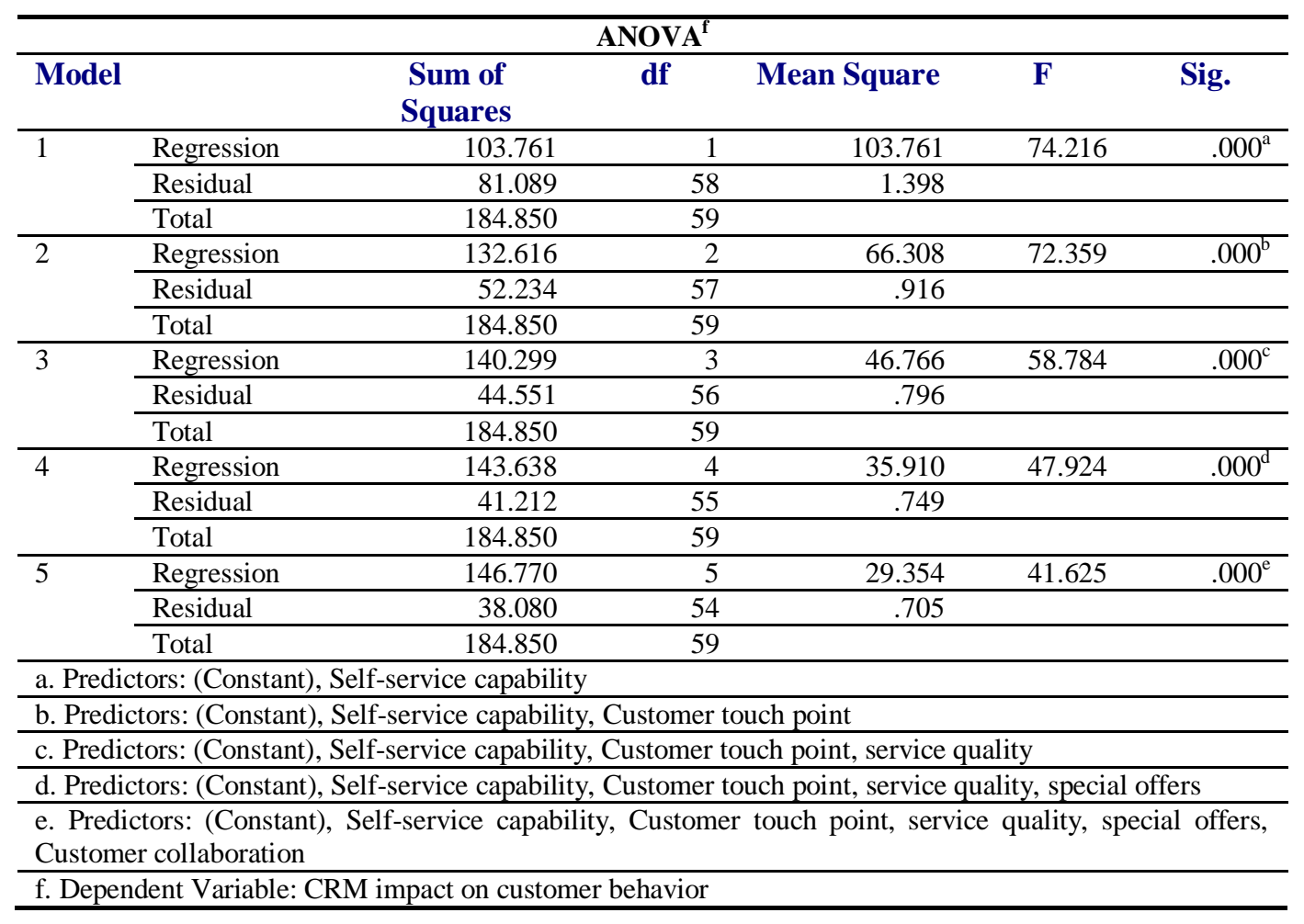

\begin{tabular}{|c|c|c|c|c|c|c|}
\hline \multicolumn{7}{|c|}{ Coefficients $^{\mathrm{a}}$} \\
\hline \multirow{2}{*}{\multicolumn{2}{|c|}{ Model }} & \multicolumn{2}{|c|}{ Unstandardized Coefficients } & \multirow{2}{*}{$\begin{array}{c}\begin{array}{c}\text { Standardized } \\
\text { Coefficients }\end{array} \\
\text { Beta } \\
\end{array}$} & \multirow[b]{2}{*}{$\mathbf{t}$} & \multirow[b]{2}{*}{ Sig. } \\
\hline & & $\mathbf{B}$ & Std. Error & & & \\
\hline \multirow[t]{2}{*}{1} & (Constant) & 1.784 & .398 & & 4.483 & .000 \\
\hline & Self-service capability & .720 & .084 & .749 & 8.615 & .000 \\
\hline \multirow[t]{3}{*}{2} & (Constant) & .697 & .376 & & 1.854 & .069 \\
\hline & Self-service capability & .479 & .080 & .499 & 5.984 & .000 \\
\hline & Customer touch point & .484 & .086 & .468 & 5.612 & .000 \\
\hline \multirow[t]{4}{*}{3} & (Constant) & .214 & .383 & & .558 & .579 \\
\hline & Self-service capability & .418 & .077 & .435 & 5.410 & .000 \\
\hline & Customer touch point & .382 & .087 & .369 & 4.394 & .000 \\
\hline & service quality & .246 & .079 & .249 & 3.107 & .003 \\
\hline \multirow[t]{5}{*}{4} & (Constant) & -.015 & .387 & & -.039 & .969 \\
\hline & Self-service capability & .307 & .091 & .320 & 3.365 & .001 \\
\hline & Customer touch point & .352 & .085 & .341 & 4.126 & .000 \\
\hline & service quality & .202 & .080 & .205 & 2.535 & .014 \\
\hline & special offers & .207 & .098 & .209 & 2.111 & .039 \\
\hline \multirow[t]{6}{*}{5} & (Constant) & .290 & .403 & & .721 & .474 \\
\hline & Self-service capability & .326 & .089 & .340 & 3.665 & .001 \\
\hline & Customer touch point & .387 & .084 & .374 & 4.579 & .000 \\
\hline & service quality & .179 & .078 & .181 & 2.293 & .026 \\
\hline & special offers & .253 & .098 & .256 & 2.595 & .012 \\
\hline & Customer collaboration & -.162 & .077 & -.150 & -2.107 & .040 \\
\hline
\end{tabular}




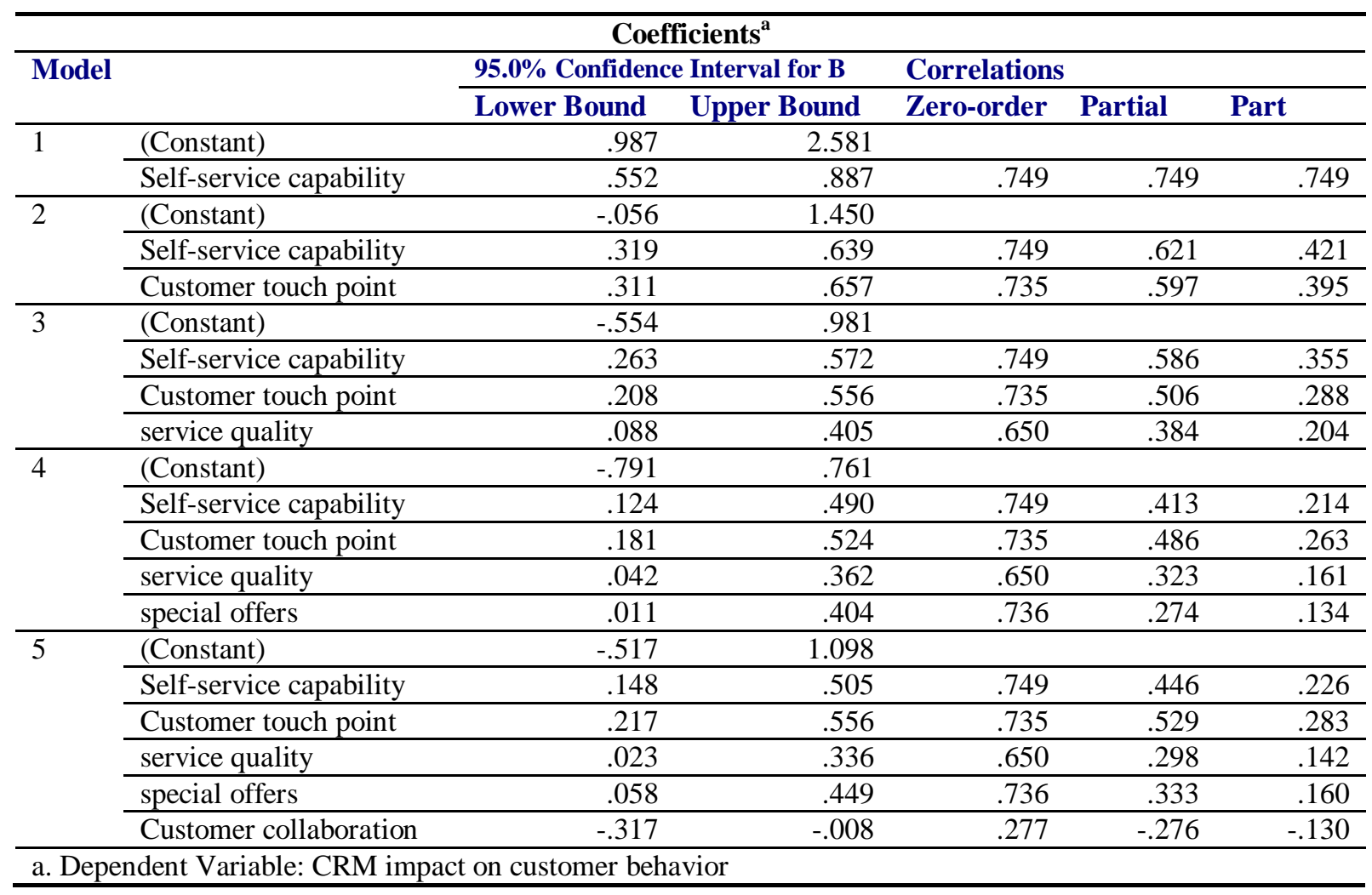

\begin{tabular}{|c|c|c|c|c|c|c|}
\hline \multicolumn{7}{|c|}{ Excluded Variables $^{f}$} \\
\hline \multirow[t]{2}{*}{ Model } & & & & & & \multirow{2}{*}{$\begin{array}{c}\text { Collinearity } \\
\text { Statistics } \\
\text { Tolerance }\end{array}$} \\
\hline & & Beta In & $\mathbf{t}$ & Sig. & $\begin{array}{c}\text { Partial } \\
\text { Correlation }\end{array}$ & \\
\hline \multirow[t]{7}{*}{1} & Customer collaboration & $-.030^{\mathrm{a}}$ & -.308 & .759 & -.041 & .837 \\
\hline & Customer touch point & $.468^{\mathrm{a}}$ & 5.612 & .000 & .597 & .713 \\
\hline & Customer feedback & $.195^{\mathrm{a}}$ & 2.073 & .043 & .265 & .812 \\
\hline & Customer relationship & $.221^{\mathrm{a}}$ & 2.510 & .015 & .315 & .896 \\
\hline & Service availability & $.272^{\mathrm{a}}$ & 2.651 & .010 & .331 & .651 \\
\hline & special offers & $.408^{\mathrm{a}}$ & 3.561 & .001 & .427 & .479 \\
\hline & service quality & $.383^{\mathrm{a}}$ & 4.489 & .000 & .511 & .780 \\
\hline \multirow[t]{6}{*}{2} & Customer collaboration & $-.126^{b}$ & -1.623 & .110 & -.212 & .800 \\
\hline & Customer feedback & $-.066^{b}$ & -.702 & .486 & -.093 & .567 \\
\hline & Customer relationship & $.124^{\mathrm{b}}$ & 1.632 & .108 & .213 & .839 \\
\hline & Service availability & $.068^{\mathrm{b}}$ & .698 & .488 & .093 & .523 \\
\hline & special offers & $.275^{\mathrm{b}}$ & 2.748 & .008 & .345 & .444 \\
\hline & service quality & $.249^{\mathrm{b}}$ & 3.107 & .003 & .384 & .668 \\
\hline \multirow[t]{5}{*}{3} & Customer collaboration & $-.108^{\mathrm{c}}$ & -1.487 & .143 & -.197 & .795 \\
\hline & Customer feedback & $-.039^{c}$ & -.437 & .664 & -.059 & .561 \\
\hline & Customer relationship & $.064^{\mathrm{c}}$ & .859 & .394 & .115 & .769 \\
\hline & Service availability & $.003^{\mathrm{c}}$ & .032 & .975 & .004 & .495 \\
\hline & special offers & $.209^{c}$ & 2.111 & .039 & .274 & .414 \\
\hline 4 & Customer collaboration & $-.150^{\mathrm{d}}$ & -2.107 & .040 & -.276 & .755 \\
\hline
\end{tabular}




\begin{tabular}{|c|c|c|c|c|c|c|}
\hline & Customer feedback & $-.030^{\mathrm{d}}$ & -.354 & .725 & -.048 & .560 \\
\hline & Customer relationship & $.091^{\mathrm{d}}$ & 1.247 & .218 & .167 & .749 \\
\hline & Service availability & $.016^{\mathrm{d}}$ & .176 & .861 & .024 & .493 \\
\hline \multirow[t]{3}{*}{5} & Customer feedback & $.035^{\mathrm{e}}$ & .395 & .695 & .054 & .491 \\
\hline & Customer relationship & $.043^{\mathrm{e}}$ & .562 & .577 & .077 & .654 \\
\hline & Service availability & $.063^{\mathrm{e}}$ & .689 & .494 & .094 & .466 \\
\hline \multicolumn{7}{|c|}{ a. Predictors in the Model: (Constant), Self-service capability } \\
\hline \multicolumn{7}{|c|}{ b. Predictors in the Model: (Constant), Self-service capability, Customer touch point } \\
\hline \multicolumn{7}{|c|}{ c. Predictors in the Model: (Constant), Self-service capability, Customer touch point, service quality } \\
\hline \multicolumn{7}{|c|}{ d. Predictors in the Model: (Constant), Self-service capability, Customer touch point, service quality, special offers } \\
\hline \multicolumn{7}{|c|}{$\begin{array}{l}\text { e. Predictors in the Model: (Constant), Self-service capability, Customer touch point, service quality, special offers, } \\
\text { Customer collaboration }\end{array}$} \\
\hline
\end{tabular}

\begin{tabular}{|c|c|c|c|}
\hline \multicolumn{4}{|c|}{$\begin{array}{l}\text { 4. Reliability } \\
\text { Scale: All Variables }\end{array}$} \\
\hline \multicolumn{4}{|c|}{ Case Processing Summary } \\
\hline & & & $\%$ \\
\hline \multirow[t]{3}{*}{ Cases } & Valid & 60 & 100.0 \\
\hline & Excluded $^{\mathrm{a}}$ & 0 & .0 \\
\hline & Total & 60 & 100.0 \\
\hline
\end{tabular}

a. Listwise deletion based on all variables in the procedure.

\begin{tabular}{rr}
\hline \multicolumn{2}{l}{ Reliability Statistics } \\
\hline $\begin{array}{c}\text { Cronbach's } \\
\text { Alpha }\end{array}$ \\
\hline \multicolumn{2}{c}{$\mathbf{N}$ of Items } \\
\hline
\end{tabular}

Factor Analysis

\begin{tabular}{llr}
\hline \multicolumn{3}{c}{ KMO and Bartlett's Test } \\
\hline & $\begin{array}{l}\text { Kaiser-Meyer-Olkin } \\
\text { Measure of Sampling }\end{array}$ & \\
& Adequacy. & .737 \\
\hline Bartlett's Test of Sphericity & Approx. Chi-Square & 83.171 \\
\cline { 2 - 3 } & df & 10 \\
\cline { 2 - 3 } & Sig. & .000 \\
\hline
\end{tabular}

\section{Correlation Matrix}

$\begin{array}{ccc}\begin{array}{c}\text { Customer } \\ \text { Collaboration }\end{array} & \begin{array}{c}\text { Service } \\ \text { Availability }\end{array} & \text { Special Offers } \\ \end{array}$

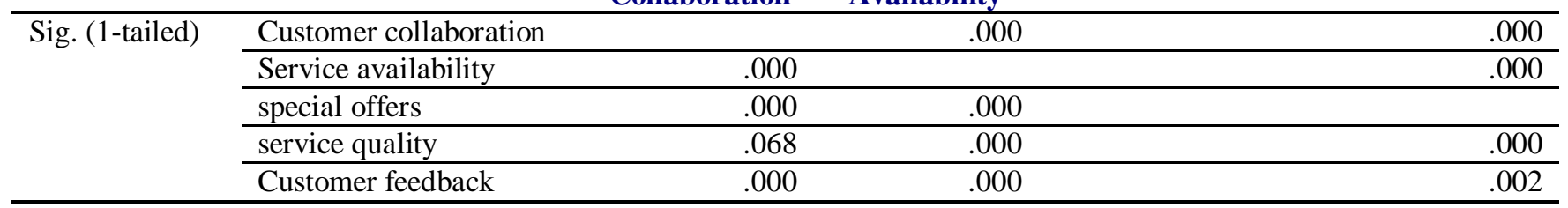

\section{Correlation Matrix}

\begin{tabular}{|c|c|c|c|}
\hline & & $\begin{array}{l}\text { Service } \\
\text { Quality }\end{array}$ & $\begin{array}{l}\text { Customer } \\
\text { Feedback }\end{array}$ \\
\hline \multirow[t]{3}{*}{ Sig. (1-tailed) } & Customer collaboration & .068 & .000 \\
\hline & Service availability & .000 & .000 \\
\hline & special offers & .000 & .002 \\
\hline
\end{tabular}




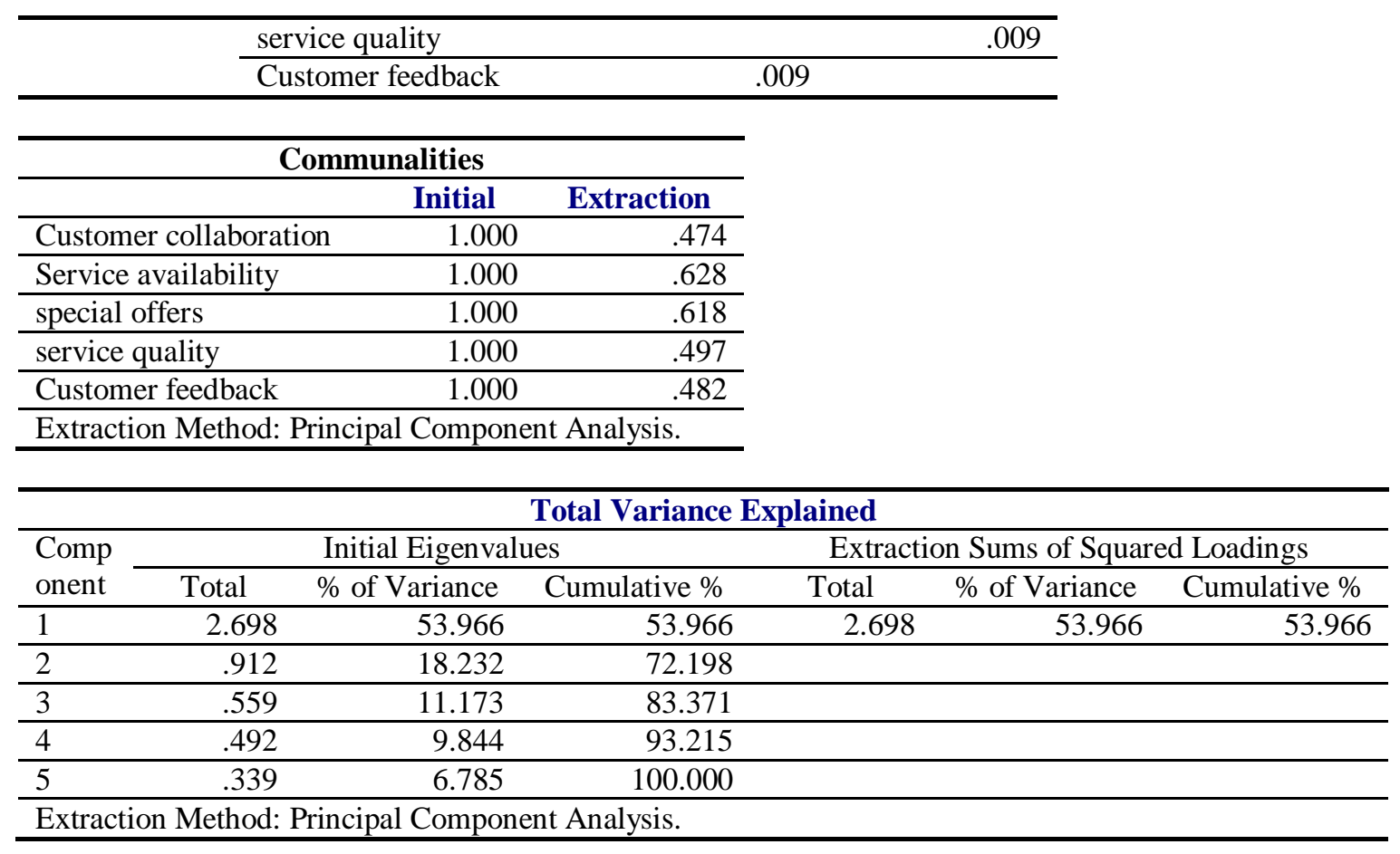

\begin{tabular}{lr}
\hline \multicolumn{2}{c}{ Component Matrix } \\
\hline \multicolumn{2}{c}{ Component } \\
\hline \multicolumn{2}{c}{1} \\
\hline Customer collaboration & .689 \\
\hline Service availability & .793 \\
\hline special offers & .786 \\
\hline service quality & .705 \\
\hline Customer feedback & .694 \\
\hline
\end{tabular}

\section{Copyrights}

Copyright for this article is retained by the author(s), with first publication rights granted to the journal. This is an open-access article distributed under the terms and conditions of the Creative Commons Attribution license (http://creativecommons.org/licenses/by/4.0/) 